\title{
The Study of Phenolic Compounds and Antioxidant Activity of Raw Materials of Reynoutria Sachalinensis (F. Schmidt) Nakai
}

Abdulrazzaq Yasir ALRIKABI, Viktoriia PROTSKA, Nadiia BURDA*, Iryna ZHURAVEL, Viktoriia KUZNETSOVA

\section{Department of Chemistry of Natural Compounds and Nutritiology, National University of Pharmacy, Kharkiv, Ukraine}

\begin{abstract}
Phenolic composition and quantitative evaluation of herbal part and root extracts for Reynoutria sachalinensis studied by HPLC method. Using the same method, we also established the antioxidant activity of $R$. sachalinensis raw materials. Six phenolic compounds were idenified for herbal part of $R$. sachalinensis as, gallic acid, chlorogenic acid, trans-cinnamic acid, rutin, hyperoside and isoquercitrin at total amount of $885 \cdot 37 \pm 21.25 \mathrm{mg} / \mathrm{kg}$. Neochlorogenic acid and rutin were found as main compounds for herbal part of $R$. sachalinensis, and gallic acid and 6,7-dihydroisoflavone were determined for root of $R$. sachalinensis. In $R$. sachalinensis roots we found gallic acid and 6,7-dihydroisoflavone.

The HPLC study of antioxidant activity showed almost identical antioxidant potential of bioactive substances (BASs) in $R$. sachalinensis herbal parts and roots that is $3.85 \pm 0.09$ and $3.59 \pm 0.09 \mathrm{mg} / \mathrm{g}$ in Trolox equivalent respectively.

The obtained data proved the feasibility of new antioxidant drugs development on the basis of $R$. sachalinensis raw materials.
\end{abstract}

Keywords: Reynoutria sachalinensis, phenolic compounds, HPLC

\section{INTRODUCTION}

Reynoutria sachalinensis (F. Schmidt) Nakai (synonyms: Polygonum sachalinensis F. Schmidt, Fallopia sachalinensis (F. Schmidt) Ronse Decr., Pleuropterus sachalinensis (F. Schmidt) H. Gross, Tiniaria sachalinensis (F. Schmidt)

\footnotetext{
*Corresponding Author: Nadiia Burda, e-mail: nadegdaburda@ukr.net ORCIDs:

Abdulrazzaq Yasir Alrikabi : :0000-0002-2791-6073

Viktoriia Protska : :0000-0002-2439-138X

Nadiia Burda : :0000-0002-7435-5731

Iryna Zhuravel : :0000-0001-8092-733X

Viktoriia Kuznetsova : : 0000-0002-4146-689X

(Received 07 August 2020, Accepted 16 Apr 2021)
} 
Janch.) is a perennial herbaceous plant of Polygonaceae family. The plant originates from East Asia, growing in Korea, Japan, the Kurile Islands and Sakhalin. This species first appeared in Europe in 1855 and has been grown at botanical gardens as an ornamental plant. $R$. sachalinensis is met as a weed in many European countries, including Ukraine ${ }^{1,2}$.

Anthraquinones (physcion, I-O-methylemodin, emodin) and stilbene (transresveratrol) possessing cytotoxic activity were separated from methanol extract of herbal part of $R$. sachalinensis ${ }^{3}$.

Another species of Reynoutria genus which is also under study, $R$. japonica, contains phenolic compounds, including flavonoids, anthraquinones, condensed tanning agents and stilbenes, polysaccharides. Extracts from $R$.japonica demonstrate antipyretic, analgesic and anti-inflammatory activities ${ }^{4}$.

HPLC/UV/ESI-MS studies of the rhizomes of $R$. japonica, $R$. sachalinensis and Reynoutria x bohemica revealed 171 compounds, comprising stilbenes, carbohydrates, procyanidins, flavan-3-ols, anthraquinones, phenylpropanoids, lignin oligomers, hydroxycinnamic acids, naphthalenes and their derivatives ${ }^{5}$.

Antimicrobial activity of acetone extract from rhizome of $R$. japonica and $R$. sachalinensis, as well as of their hybrid Reynoutria x bohemica was studied as regards the caries-inducing pathogens, against Streptococcus mutans. The most active extract was found for R. japonica rhizome $e^{6}$.

In Ukraine R. sachalinensis is not a pharmacopoeia-registered plant, still, issuing from the experience of folk medicine application of this plant in East Asian countries as well as from the results of scientific research, we may foresee its feasibility for medical drugs development.

As the oxidative stress in human organism may provoke the diseases of different severity, including cancers, atherosclerosis, neurodegenerative diseases (Parkinson's, Alzheimer's, etc.), hypertension, diabetes mellitus, cardiovascular diseases, reproductive system dysfunctions, etc, search of promising antioxidants of herbal origin has become an important aspect in pharmacy ${ }^{7-12}$.

Antioxidant activity were studied of phenolic compounds as, anthraquinones (emodin, emodin-8-O-beta-D-glucopyranoside and physcion-8-O-beta-Dglucopyranoside) and flavonoids (quercetin-3-O-alpha-L-arabinofuranoside, quercetin-3-O-beta-D-galactopyranoside and quercetin-3-O-beta-D-glucuronopyranoside) for flower extracts of $R$. sachalinensis in our previous study ${ }^{13}$. Therefore, for deeper understanding of $R$. sachalinensis application prospects, it turned out feasible to study phenolic substances in herbal and roots extracts 
of this plant as well as its antioxidant activity. We conducted a comparative study of $R$. sachalinensis herbal parts and roots.

\section{METHODOLOGY}

\section{Plant materials}

In experiments we used air-dried milled roots and herbal parts of $R$. sachalinensis. Herbal parts were collected within blossoming period in June, roots - in September in Kharkiv Region, Ukraine during 2018-2019.

The plant material sample was identified by Prof. Tatyana Gontova, Department of Botany, National University of Pharmacy, Ukraine and voucher specimens were deposited at National University of Pharmacy, Ukraine.

\section{Extraction}

Extracts for analysis were prepared by extracting $0.3 \mathrm{~g}$ milled raw material with $10 \mathrm{~mL}$ methanol within $20 \mathrm{~min}$ on ultrasonic bath at $20 \pm 2{ }^{\circ} \mathrm{C}$. The obtained extracts were filtered through a membrane filter $(0.45 \mu \mathrm{m})^{14}$.

\section{General experimental procedures}

For study of phenolic compounds in $R$. sachalinensis, as well as determination of antioxidant activity by HPLC method (Waters Corporation, Milford, USA) with Waters 996 PDA photodiode matrix detector, (Waters Corporation, USA), Wise Clean WUC-Ao6H ultrasonic cleaning set (Daihan, Korea), ANG 100 analytical balance (AXIC, Poland), standard samples of substances and solvents for chromatographic analysis from Merck KGaA (Darmstadt, Germany).

\section{Chromatographic analysis by HPLC}

Chromatographic separation of phenolic compounds was performed using ACE 5 C18 column $250 \mathrm{~mm} \times 4.6 \mathrm{~mm}$ (Pennsylvania, USA). Elution flow rate was 1 $\mathrm{ml} / \mathrm{min}$. Mobile phase binary solvent system consisted of solvent A (o.1\% acetic acid aqueous solution) and solvent B (acetonitrile). All solvents passed ultrasonic degassing and $0.23 \mu \mathrm{m}$ pore size membrane filter. Linear gradient program looked as follows:

$\begin{array}{ccc}\text { Time, min } & \text { Solvent A, } \% & \text { Solvent B, \% } \\ 0-8 & 5-15 & 95-85 \\ 8-30 & 15-20 & 85-80 \\ 30-48 & 20-40 & 80-60 \\ 48-58 & 40-50 & 60-50 \\ 58-65 & 50 & 50 \\ 65-66 & 50-95 & 50-5\end{array}$


The column had constant temperature of $25^{\circ} \mathrm{C} .10 \mu$ samples were injected ${ }^{13}$. For determination of antioxidant activity after application of HPLC-PDA detector system the mobile phase containing tested samples was fed with Gilson 305 pump (Middleton, WI, USA) to the column via mixing tee with ABTS reagent in split relation 1:1. A Teflon column (Waters PCR module, Milford, CT, USA) 3 $\mathrm{m}$ long and $0.25 \mathrm{~mm}$ in diameter was used, its granularity being $1.58 \mu \mathrm{m}$. ABTS solution system control parameters: column temperature circa $50^{\circ} \mathrm{C}$, mobile phase flow rate $0.5 \mathrm{ml} / \mathrm{min}^{15,16}$.

Sample color change in mixture with ABTS reagent after reaction ending was recorded using Waters 2487 UV/VIS detector (Waters Corporation) at wavelength of $650 \mathrm{~nm}$.

In selection of analysis terms we were guided by the signal value expressed in negative peak height as a sensitivity indicator. The antioxidant potential of tested samples was determined by the comparison with that of Trolox standard solution in eight different concentrations within the range of $0.625-80 \mathrm{mg} / \mathrm{ml}$. The constructed calibration plot was expressed with the following quadratic equation:

$\mathrm{Y}=-1.54 \cdot 10^{2} \mathrm{X}^{2}+4.16 \cdot 4.16 \cdot 10^{4} \mathrm{X}-2.08 \cdot 10^{4} ; \mathrm{R}^{2}(\mathrm{ABTS})=0.9991$.

Antioxidant potential of extracts (X, mg/g) was calculated by formula:

$X=\frac{\mathrm{m}_{0} \cdot 20000}{\mathrm{~m}_{1} \cdot(100-\mathrm{w})}$

where $m_{0}$ - mass of Trolox standard sample, $g ; m_{1}$ - mass of tested sample, $g$; $\mathrm{w}$ - drying loss, wt $\%^{14,15}$.

\section{RESULTS AND DISCUSSION}

The results of our study enabled the identification of six phenolic compounds in $R$. sachalinensis herbal parts: phenolcarbonic gallic acid, two hydroxycinnamic acids (neochlorogenic, trans-cinnamic) and three flavonoids (rutin, hyperoside and isoquercitrin). In roots of this plant we found only gallic acid and 6,7-dihydroisoflavone. HPLC chromatograms of phenolic compounds in $R$. sachalinensis herbal parts and roots are shown in Fig. 1-2. 


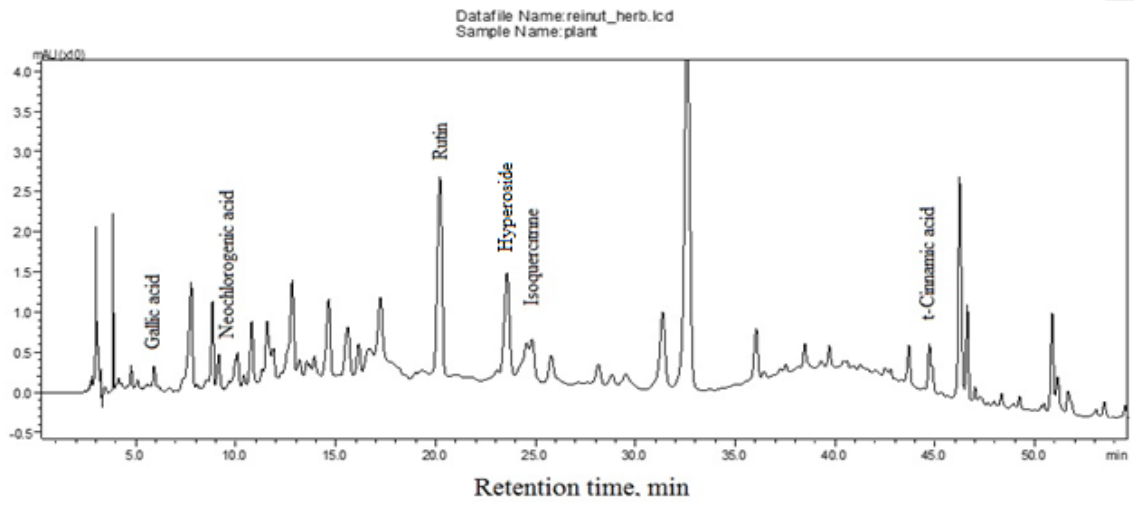

Figure 1. HPLC chromatogram of phenolic compounds in $R$. sachalinensis herbal parts

Datafile Name:reinut_roots.lcd Sample Name:plant

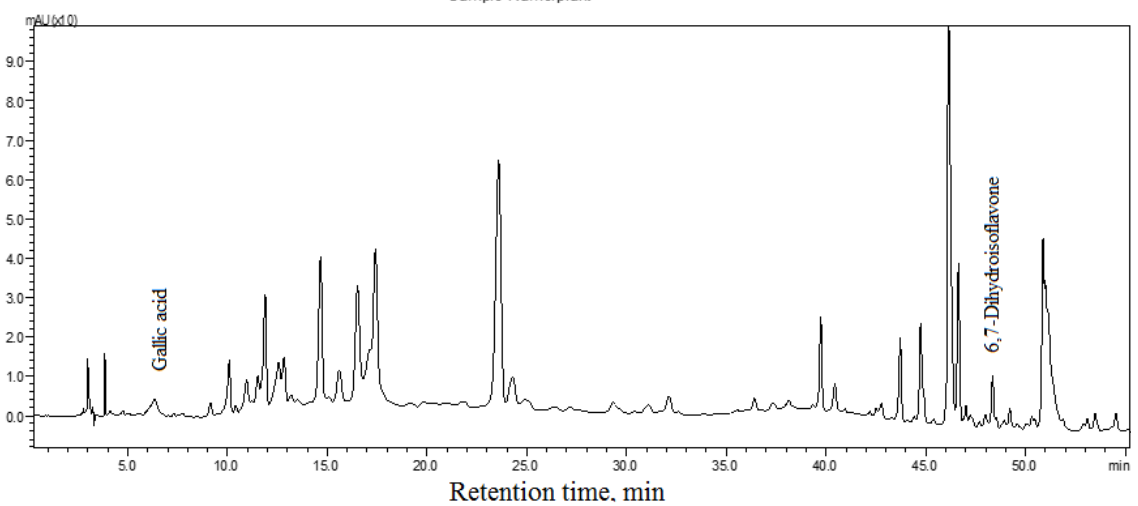

Figure 2: HPLC chromatogram of phenolic compounds in $R$. sachalinensis roots 
The qualitative composition and quantitative content of phenolic compounds in $R$. sachalinensis herbal parts and roots are presented in Table 1.

Table 1. Qualitative composition and quantitative content of phenolic compounds of $R$. sachalinensis raw materials

\begin{tabular}{|c|c|c|c|c|}
\hline \multirow[b]{2}{*}{ Compound } & \multicolumn{2}{|c|}{ Herbal parts } & \multicolumn{2}{|c|}{ Roots } \\
\hline & $\begin{array}{l}\text { Retention time, } \\
\text { min }\end{array}$ & $\begin{array}{l}\text { Quantitative } \\
\text { content, } \mathrm{mg} / \mathrm{kg}\end{array}$ & $\begin{array}{l}\text { Retention time, } \\
\text { min }\end{array}$ & $\begin{array}{l}\text { Quantitative } \\
\text { content, } \mathrm{mg} / \mathrm{kg}\end{array}$ \\
\hline \multicolumn{5}{|c|}{ Phenolic acids } \\
\hline Gallic acid & 5.91 & $21.99 \pm 0.55$ & 5.91 & $6.98 \pm 0.17$ \\
\hline $\begin{array}{l}\text { Total content of } \\
\text { phenolic acids }\end{array}$ & - & $21.99 \pm 0.55$ & - & $6.98 \pm 0.17$ \\
\hline \multicolumn{5}{|c|}{ Cinnamic acids } \\
\hline Neochlorogenic acid & 8.84 & $407.17 \pm 8.56$ & - & - \\
\hline trans -Cinnamic acid & 44.72 & $23.39 \pm 0.47$ & - & - \\
\hline $\begin{array}{l}\text { Total content of } \\
\text { cinnamic acids }\end{array}$ & - & $430.56 \pm 9.90$ & - & - \\
\hline \multicolumn{5}{|c|}{ Flavonoids } \\
\hline Rutin & 20.52 & $189.72 \pm 4.55$ & - & - \\
\hline Hyperoside & 24.55 & $115.61 \pm 2.54$ & - & - \\
\hline Isoquercitrin & 24.83 & $127.49 \pm 2.93$ & - & - \\
\hline $\begin{array}{c}\text { 6,7-Dihydroisofla- } \\
\text { vone }\end{array}$ & - & - & 47.99 & $10.32 \pm 0.24$ \\
\hline $\begin{array}{l}\text { Total content of } \\
\text { flavonoids }\end{array}$ & - & $432.82 \pm 10.82$ & - & $10.32 \pm 0.24$ \\
\hline $\begin{array}{l}\text { Total content of } \\
\text { identified com- } \\
\text { pounds }\end{array}$ & - & $885.37 \pm 21.25$ & - & $17.30 \pm 0.43$ \\
\hline
\end{tabular}

Results are expressed as means \pm SD of three measurements; $\mathrm{p}<0.05$; «-»not identified

The total content of identified compounds in $R$. sachalinensis herbal parts was $885.37 \pm 21.25 \mathrm{mg} / \mathrm{kg}$. The amounts of hydroxycinnamic acids and flavonoids in this plant: $430.56 \pm 9.90$ and $432.82 \pm 10.82 \mathrm{mg} / \mathrm{kg}$ respectively. Gallic acid $(21.99 \pm 0.55$ $\mathrm{mg} / \mathrm{kg}$ ) accounted for circa $2.5 \%$ of the total content of identified compounds.

Neochlorogenic acid and rutin dominated in $R$. sachalinensis herbal parts. This raw material contained $407.17 \pm 8.56 \mathrm{mg} / \mathrm{kg}$ chlorogenic acid, $189.72 \pm 4.55 \mathrm{mg} /$ $\mathrm{kg}$ rutin, $115.61 \pm 2.54 \mathrm{mg} / \mathrm{kg}$ hyperoside and $127.49 \pm 2.93 \mathrm{mg} / \mathrm{kg}$ isoquercitrin.

The total content of identified phenolic compounds in $R$. sachalinensis roots was $17.30 \pm 0.43 \mathrm{mg} / \mathrm{kg}$. Gallic acid content in this part of plant was 3.3 times less than in its herbal parts. 6,7-dihydroisoflavone $(10.32 \pm 0.24 \mathrm{mg} / \mathrm{kg}) \mathrm{ac}-$ counted for almost $60 \%$ of the sum of identified compounds. 
Antioxidant activity of bioactive substances in $R$. sachalinensis herbal parts and roots were studied in vitro by HPLC method in Trolox equivalent. Antioxidant activity chromatograms of $R$. sachalinensis herbal parts are shown in Fig. 3, that of the roots in Fig. 4 .

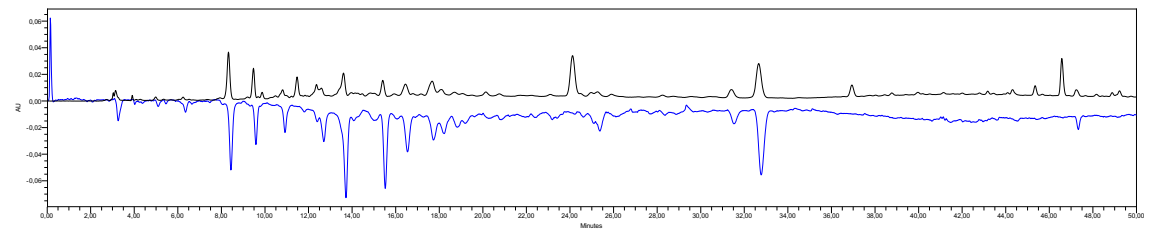

Figure 3: HPLC chromatogram of antioxidant activity determoination of $R$. sachalinensis herbal parts

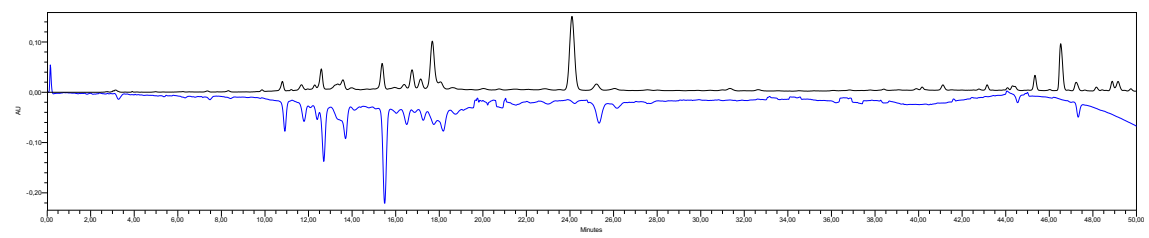

Figure 4: HPLC chromatogram of antioxidant activity determibation in $R$. sachalinensis roots

The experimental results are presented in Table 2.

Table 2. Antioxidant activity of BASs in $R$. sachalinensis raw materials

\begin{tabular}{|c|c|}
\hline Extracts & Antioxidant capacity in Trolox equivalent, $\mathbf{m g} / \mathbf{g}$ \\
\hline Herbal part of extract & $3.85 \pm 0.09$ \\
\hline Roots & $3.59 \pm 0.09$ \\
\hline
\end{tabular}

Results are expressed as means \pm SD of three measurements; $\mathrm{p}<0.05$.

The obtained data showed that antioxidant activities of bioactive substances in $R$. sachalinensis herbal parts and roots were in close proximity and made $3.85 \pm 0.09$ and $3.59 \pm 0.09 \mathrm{mg} / \mathrm{kg}$ respectively.

Our research proved much higher versatility of phenolic compounds composition in $R$. sachalinensis herbal parts as compared to its roots. The quantitative content of those bioactive substances was much higher in $R$. sachalinensis herbal parts. The study of antioxidant activity confirmed that the antioxidant potential of both parts of tested plant was almost at an identical level. The obtained data enable our deeper knowledge of $R$. sachalinensis chemical composition and pharmacological activity and confirm the feasibility of drugs devel- 
opment on the basis of $R$. sachalinensis raw materials, including drugs with antioxidant activity. Besides, this information will be useful in the development of quality control methods for $R$. sachalinensis raw materials.

\section{ACKNOWLEDGMENTS}

This research did not receive any specific grant from funding agencies in the public, commercial, or not-forprofit sectors.

\section{CONFLICT OF INTEREST}

The authors declare no conflict of interest. 


\section{REFERENCES}

1. Širka VH, Lakušić D, Šinžar-Sekulić J, Nikolić T, Jovanović S. Reynoutria sachalinensis: a new invasive species to the flora of Serbia and its distribution in SE Europe. Bot Serb, 2013; 37(2): 105-112.

2. Alrikabi AYa, Tartynska HS, Zhuravel IO. A study in elementary composition of Sakhalin knotweed (Reynoutria sachalinensis (F. Schmidt) Nakai) herb. Fitoterapiia. A Journal, 2019; 1: 70-72. - in Ukrainian. https://doi.org/10.33617/2522-9680-2019-1-70

3. Jin W, Na MK, Song GY, Lee YM, Bae KH. Cytotoxic anthraquinones and stilbenes from Reynoutria sachalinensis (Fr. Schm.) Nakai. Korean Journal of Medicinal Crop Science, 2oo5; 13(2): 80-84.

4. Patocka J, Navratilova Z, Ovando M. Biologically active compounds of Knotweed (Reynoutria spp.). Mil Med Sci Lett (Voj. Zdrav. Listy), 2017; 86(1): 17-31.

5. Nawrot-Hadzik I; Ślusarczyk S; Granica S; Hadzik J; Matkowski A. Phytochemical Diversity in Rhizomes of Three Reynoutria Species and their Antioxidant Activity Correlations Elucidated by LC-ESI-MS/MS Analysis. Molecules, 2019; 24(6): 1136. https://doi.org/10.3390/ molecules24061136

6. Nawrot-Hadzik I, Hadzik J, Fleischer M, Choromańska A, Sterczała B, Kubasiewicz-Ross P, et al. Chemical composition of East Asian invasive Knotweeds, their cytotoxicity and antimicrobial efficacy against cariogenic pathogens: an in-vitro study. Med Sci Monit, 2019; 25: 3279-3287. https://doi.org/10.12659/MSM.913855

7. Uttara B, Singh AV, Zamboni P, Mahajan RT. Oxidative stress and neurodegenerative diseases: a review of upstream and downstream antioxidant therapeutic options. Curr Neuropharmacol, 2009; 7(1): 65-74. https://doi.org/10.2174/157015909787602823

8. Gupta RK, Patel AK, Shah N, Choudhary AK, Jha UK, Yadav UC, et al. Oxidative stress and antioxidants in disease and cancer: a review. Asian Pac J Cancer Prev, 2014; 15: 4405-4409. https://doi.org/10.7314/apjcp.2014.15.11.4405

9. Vaziri ND, Rodríguez-Iturbe B. Mechanisms of disease: oxidative stress and inflammation in the pathogenesis of hypertension. Nat Clin Pract Nephrol, 2oo6; 2: 582-593. https://doi. org/10.1038/ncpnepho283

10. Pohanka M. Alzheimer's disease and oxidative stress: a review. Curr Med Chem, 2014; 21(3): 356-364. https://doi.org/10.2174/09298673113206660258

11. Kruk J, Aboul-Enein HY, Kładna A, Bowser JE. Oxidative stress in biological systems and its relation with pathophysiological functions: the effect of physical activity on cellular redox homeostasis. Free Radic Res, 2019; 53(5): 497-521. https://doi.org/10.1080/10715762.2019.1612059

12. Pohanka M. Role of oxidative stress in infectious diseases. A review. Folia Microbiol, 2013; 58: 503-513. https://doi.org/10.1007/s12223-013-0239-5

13. Zhang X, Thuong PT, Jin WY, Su N.D, Sok DE, Bae KH, et al. Antioxidant activity of anthraquinones and flavonoids from flower of Reynoutria sachalinensis. Arch Pharm Res, 2005; 28(1): 22-27. https://doi.org/10.1007/BFo2975130

14. Glushchenko A, Bezruk I, Ivanauskas L, Georgiyants V. Development of the method of simultaneous quantitative determination of loratadine and auxuilary substances in the combined syrup «Loratadin+». ScienceRise: Pharmaceutical Science, 2019; 2(18): 39-47. https://doi. org/10.15587/2519-4852.2019.169511 
15. Raudonis R., Raudone L, Jakstas V, Janulis V. Comparative evaluation of post-column free radical scavenging and ferric reducing antioxidant power assays for screening of antioxidants in strawberries. J Chromatogr A, 2012; 1233: 8-15. https://doi.org/10.1016/j.chroma.2012.02.019

16. Raudonis R, Jakštas V, Burdulis D, Benetis R., Janulis V. Investigation of contribution of individual constituents to antioxidant activity in herbal drugs using postcolumn HPLC method. Medicina, 2009; 45(5): 382-394. 